ENGINEERING CHANGE NOTICE

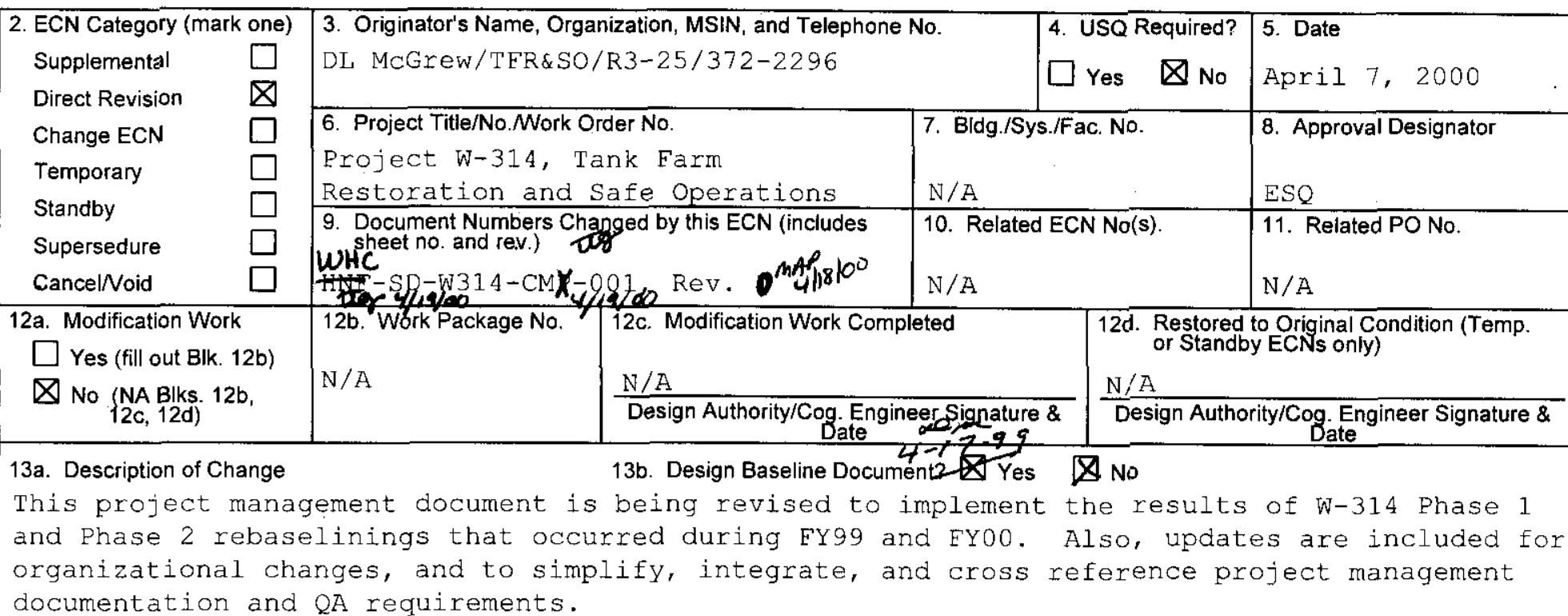

documentation and $\mathrm{QA}$ requirements.

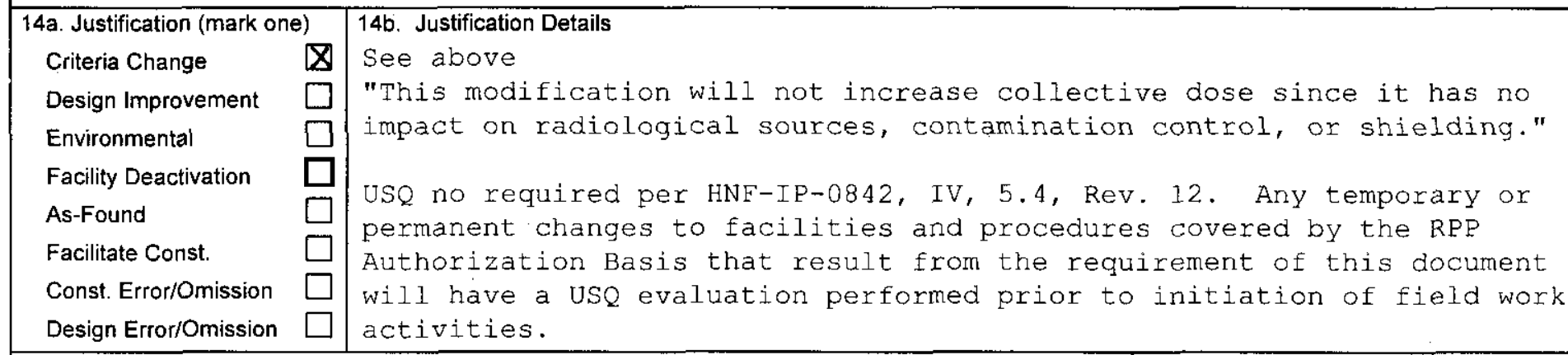

15. Distribution (include name, MSIN, and no. of copies)

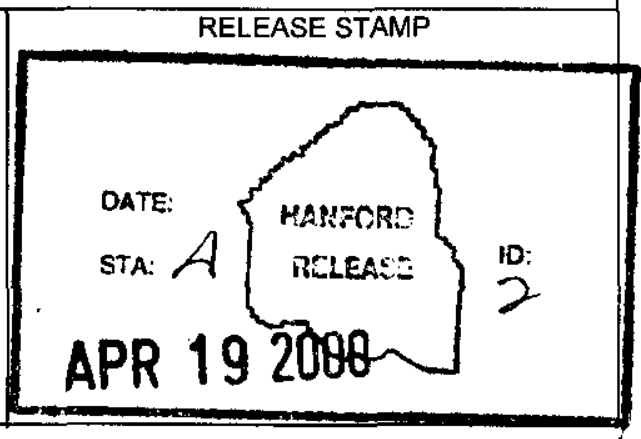




\section{ENGINEERING CHANGE NOTICE}

16. Design Verification Required

$\square$ Yes

$\triangle$ No
17. Cost Impact

ENGINEERING

Additional

Savings $\square \$$
$\$ N / A$

$\$$
Page 2 of 2

CONSTRUCTION

Additional $\square \$ \underline{N} / \mathrm{A}$

Savings
1. ECN (use no. from pg. 1)

656162

18. Schedule Impact (days)

mprovement $\square$ N/A

Delay

19. Change Impact Review: Indicate the related documents (other than the engineering documents identified on Side 1) that will be affected by the change described in Block 13. Enter the affected document number in Block 20.

$\begin{array}{lll}\text { SDD/DD } & \text { Seismic/Stress Analysis } \\ \text { Functional Design Criteria } & \square & \text { Stress/Design Report } \\ \text { Operating Specification } & \square & \text { Interface Control Drawing } \\ \text { Criticality Specification } & \square & \text { Calibration Procedure } \\ \text { Conceptual Design Report } & \square & \text { Installation Procedure } \\ \text { Equipment Spec. } & \square & \text { Maintenance Procedure } \\ \text { Const. Spec. } & \square & \text { Engineering Procedure } \\ \text { Procurement Spec. } & \square & \text { Operating Instruction } \\ \text { Vendor Information } & \square & \text { Operating Procedure } \\ \text { OM Manual } & \square & \text { Operational Safety Requirement } \\ \text { FSAR/SAR } & \square & \text { IEFD Drawing } \\ \text { Safety Equipment List } & \square & \text { Cell Arrangement Drawing } \\ \text { Radiation Work Permit } & \square & \text { Essential Material Specification } \\ \text { Environmental Impact Statement } \\ \text { Environmental Report }\end{array}$

\begin{tabular}{lll}
$\square$ & Tank Calibration Manual & $\square$ \\
$\square$ & Health Physics Procedure & $\square$ \\
$\square$ & Spares Multiple Unit Listing & $\square$ \\
$\square$ & Test Procedures/Specification & $\square$ \\
$\square$ & Component Index & $\square$ \\
$\square$ & ASME Coded Item & $\square$ \\
$\square$ & Human Factor Consideration \\
$\square$ & Computer Software & $\square$ \\
$\square$ & Electric Circuit Schedule & $\square$ \\
$\square$ & Process Control ManualPlan & $\square$ \\
$\square$ & Process Flow Chart & $\square$ \\
\hline
\end{tabular}

20. Other Affected Documents: (NOTE: Documents listed below will not be revised by this ECN.) Signatures below indicate that the signing organization has been notified of other affected documents listed below.

None

21. Approvals

Signature

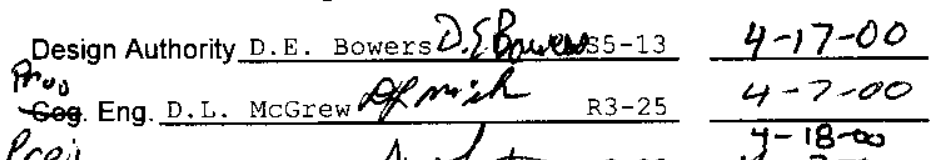
Cog. Mgr. J.W. Lentsch hw fent R3-35 $\quad 1-7-0$

QA T.L. Benningtor

Safety T.J. Volkman

1. Tog

- Environ.

Other

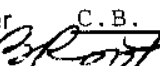
R2-58 Prog. Interface R. W Root R2-53
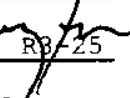

$4-18-00$

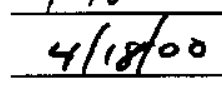

is/12/is

$04-18-00$

$41 / 9100$
Signature

Date

Design Agent

PE

QA

Safety

Design

Environ.

Other

\section{DEPARTMENT OF ENERGY}

Signature or a Control Number that tracks the Approval Signature

ADPITIONAL 


\section{Configuration Management Plan for Tank Farm Restoration and Safe Operations, Project W-314}

\section{I. MoGrow}

Numatec Hanford Corporation

Richland, WA 99352

U.S. Department of Energy Contract DE-AC06-86RL13200

EDT/ECN: 656162

Org Code: 7c300

B\&R Code:
UC:

Charge Code: 109749

Total Pages: II

Key Words:

Management Plan, Tank Farm Restoration and Saf3. 6 Configura Operations, Office of River Protection, Project $w-314$.

Abstract: The Configuration Management Plan for Project $\mathrm{W}-314$ describes the systems, processes and procedures for implementation of applicable configuration management practices described in HNF-0842, Volume III, Section 3.1, "Configuration Management Implementation". This plan is tailored specifically for use by Project $W-314$.

TRADEMARK DISCLAIMER. Reforence herein to any specilic commercial product, process, or service by trade name, trademark, manufucturer, or otherwice, does not neceseanlly conetitute or imply is endorsement, recommendation, or favoring by the United States Government or any agency thereof or its contractors or aubcontractors.

Printed in the United States of America. To obtain coples of this document, contact: Document Control Services, P.O. Box 950, Mallotop H6-08, Richland WA 90352, Phone (509) 372-2420; Fax (509) 376-4989.

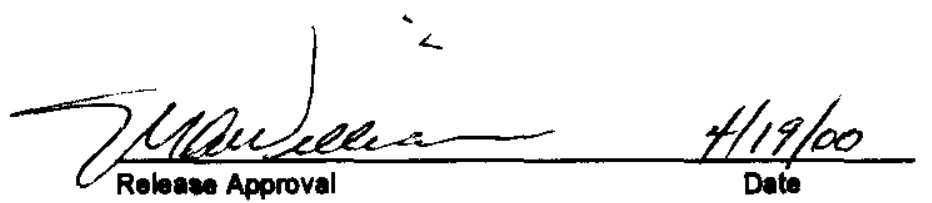

Release Approval

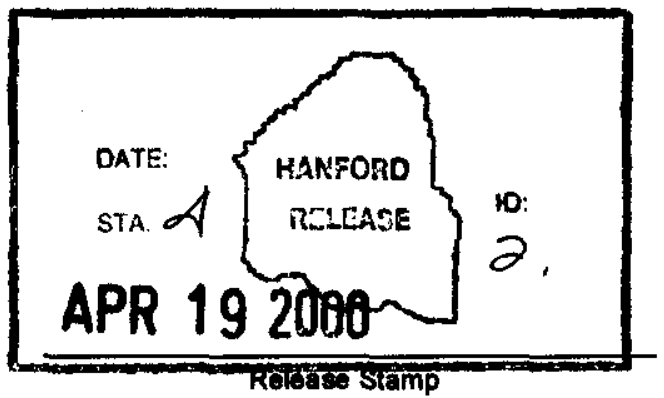




\section{RECORD OF REVISION}

(1) Document Number $\mathrm{A}_{44} 401$
$\mathrm{HNE}-\mathrm{SD}-\mathrm{W} 314-\mathrm{CM}-001$

(2). Title

Configuration Management Plan for Tank Farm Restoration and Safe Operations, Project W-314

Change Control Record

(3) Revision

0

(7)

Released - EDT 606469, 12/15/1995

1 RS Direct Revision - ECN 656162

\section{Authorized for Release}

\begin{tabular}{l|l} 
(5) Cog. Engr. & (6) Cog. Mgr. Date
\end{tabular}

MA Smith- WW Rutherford

Fewel1

DL MCGrew JW Lentsch

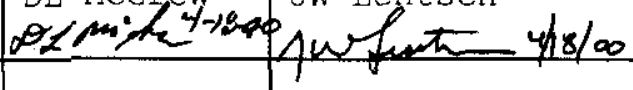




\title{
CONFIGURATION MANAGEMENT PLAN
}

\author{
For
}

\section{TANK FARM RESTORATION}

AND SAFE OPERATIONS

PROJECT W-314

Prepared for the

U.S. Department of Energy

Office of River Protection

by

CH2M HILL Hanford Group, Inc.

Revised

April 2000 


\section{TABLE OF CONTENTS}

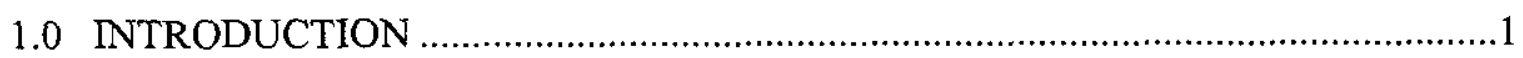

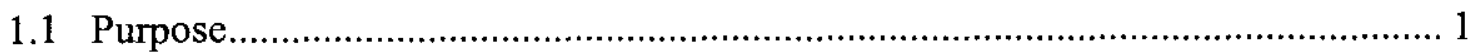

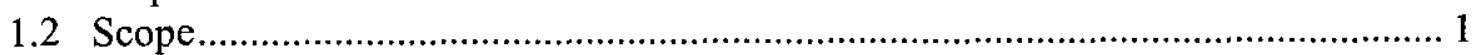

2.0 ROLES AND RESPONSIBILITIES ……………...............................................

2.1 U.S. Department of Energy, Office of River Protection.......................................... 1

2.2 CH2M HILL Hanford Group .............................................................................. 2

2.2.1 W-314 Project Management …….......................................................... 2

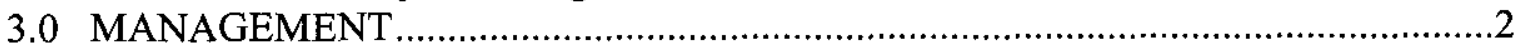

3.1 Configuration Management of Cost and Schedule Baseline .................................. 2

3.2 Configuration Management of the Technical Baseline …….................................. 2

3.3 Configuration Management of the Design Media in Development........................ 3

3.4 Configuration Management of Design During Procurement and Construction ..... 3

3.5 Configuration Management of Design During at the End of Construction ............. 3

3.6 Configuration Management of the Project Interfaces .............................................. 3

3.7 Configuration Management of the Quality Requirements..................................... 3

3.8 Configuration Management of Supporting Documents .......................................... 3

3.9 Management of "In-Process Information" ............................................................. 4

3.10 Configuration Management of Control System Software ..................................... 4

3.11 Configuration Management of Vendor Submittal Information ............................. 4

3.12 Drawings .................................................................................................. 4

3.13 Configuration Management of "Turn-Over Documentation".................................. 4

3.14 Configuration Management of the W-314 RDD-100 Database ............................... 5

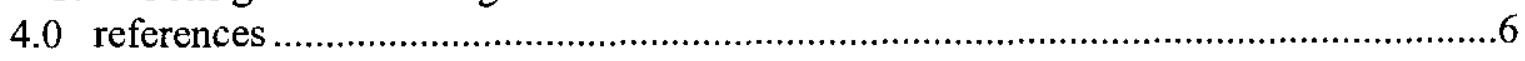




\section{ACRONYMS AND ABBREVIATIONS}

$\begin{array}{ll}\text { CM } & \text { configuration management } \\ \text { CMP } & \text { configuration management plan } \\ \text { DOE } & \text { U.S. Department of Energy } \\ \text { ECN } & \text { Engineering Change Notice } \\ \text { FFS } & \text { Fluor Federal Services, Inc. } \\ \text { HDCS } & \text { Hanford Document Control System } \\ \text { HMI } & \text { Human-Machine Interface } \\ \text { CHG } & \text { CH2M HILL Hanford Group } \\ \text { LMSI } & \text { Lockheed Martin Services, Inc. } \\ \text { MPSS } & \text { Master Pump Shutdown System } \\ \text { ORP } & \text { Office of River Protection } \\ \text { PICD } & \text { Project Interface Control Document } \\ \text { PLC } & \text { Programmable Logic Controller } \\ \text { PMP } & \text { Project Management Plan } \\ \text { QTP } & \text { Qualification Test Procedure } \\ \text { RL } & \text { U.S. Department of Energy, Richland Operations Office } \\ \text { RPP } & \text { River Protection Project } \\ \text { SCMP } & \text { Software Configuration Management Plan } \\ \text { SD } & \text { Supporting Document } \\ \text { SSC } & \text { Structure, system, and component }\end{array}$




\subsection{INTRODUCTION}

The Configuration Management Plan for Project W-314 (CMP), HNF-SD-W314-CMP001 , describes the systems, processes and procedures for implementation of applicable configuration management practices described in HNF-IP-0842, Vol. III, Sec. 3.1, Configuration Management Implementation. This plan is tailored specifically for use by Project W-314.

\subsection{Purpose}

The Project W-314 CMP provides an integrated approach to control the technical, cost, schedule, and administrative information necessary to manage W-314's baseline.

\subsection{Scope}

The CMP applies to both Phase 1 and Phase 2 of execution activities of W-314. The activities covered by this plan are:

- Configuration Management of the cost and schedule baseline

- Configuration Management of the technical baseline

- Configuration Management of the design media in development

- Configuration Management of the design during procurement and construction

- Configuration Management of the design at the end of construction

- Configuration Management of the Project's interfaces

- Configuration Management of the Quality Requirements

- Configuration Management of Supporting Documents

- Configuration Management of "In-Process Information"

- Configuration Management of Control System Software

- Configuration Management of Vendor Submittal Information

- Configuration Management of "Turn-Over Documentation

- Configuration Management of the W-314 RDD-100 Database

\subsection{ROLES AND RESPONSIBILITIES}

Roles and responsibilities are defined to ensure that functional organizations are aware of the roles and responsibilities required for implementation of the configuration management $(\mathrm{CM})$ program. This section of the CMP identifies general organizational roles and responsibilities related to $\mathrm{CM}$.

\subsection{U.S. Department of Energy, Office of River Protection}

The Office of River Protection (ORP) shall participate in W-314 CM, as required for the initial project baseline approvals, project baseline change control approvals, and Authorization Basis control and maintenance, as applicable per the following procedures: 
- RPP-PRO-1997, Construction Program Overview

- RPP-PRO-233, Review and Approval of Documents

- HNF-IP-0842, Vol. VIII, Sec. 1.1, Baseline Change Control

\subsection{CH2M HILL Hanford Group}

As the contractor responsible for the RPP, CH2M HILL Hanford Group (CHG) establishes and manages the RPP-specific CM program by developing and establishing requirements and appropriate implementing procedures that address $\mathrm{CM}$ responsibilities and process methodologies. Other RPP CM roles and responsibilities are described in HNF-SD-W314-PMP-001, Project Execution Plan for Project $W-314$.

\subsubsection{W-314 Project Management}

W-314 Project Management shall implement Configuration Management within the boundaries of the Project as depicted in Section 3.0 and as described in HNF-SD-W314PMP-001, Project Execution Plan for Project $W-314$.

\subsection{MANAGEMENT}

The management element directs and monitors the development and implementation of the W-314 CMP. The CMP maintains the project scope, baselines, concepts (organizational and physical), and specifies the implementation procedures and methodologies for the project.

\subsection{Configuration Management of Cost and Schedule Baseline}

The Project W-314 cost and schedule baseline is accomplished using a disciplined change control process in accordance with HNF-IP-0842, Vol. VIII, Sec. 1.1, Baseline Change Control. Cost and schedule changes are proposed and processed using the standard change request form, approved at the Project, RPP, or ORP level depending on the significance of the change. Project W-314 change requests are recorded on the Project W-314 Change Control Log.

\subsection{Configuration Management of the Technical Baseline}

Configuration management of the design baseline is accomplished in accordance with the requirements of procedures RPP-PRO-244, Engineering Data Transmittal Requirements, HNF-IP-0842, Vol. IV, Sec. 2.18, Engineering Release and Approval Requirements, and HNF-IP-0842, VOL. IV, SEC. 4.29, Engineering Document Change Control Requirements. A definitive list of the design baseline documents exists in RPP-6185, System Engineering Management Plan for Tank Farm Restoration and Safe Operations, Project $W-314$. 


\subsection{Configuration Management of the Design Media in Development}

As Title II designs are developed, the in-process design media is periodically issued for review. In order to provide traceability to the design evolution, in-process media is dated prior to printing and reproduction.

\subsection{Configuration Management of Design During Procurement and Construction}

Configuration Management of design during procurement and construction is accomplished in accordance with the requirements of procedures RPP-PRO-244, Engineering Data Transmittal Requirements, HNF-IP-0842, Vol. IV, Sec. 2.18, Engineering Release and Approval Requirements, and HNF-IP-0842, VOL. IV, SEC. 4.29, Engineering Document Change Control Requirements and HNF-IP-0842, Vol. IV, Sec. 4.20, Engineering Specification Requiements.

\subsection{Configuration Management of Design During at the End of Construction}

Configuration Management of design at the end of construction is accomplished via appropriate field verification of the installed systems, structures and components (SSC); the as-builting of drawings and specifications; and the release of essential and support drawings into the engineering document system for use by the facility in Configuration Management of the facility's SSCs. Revisions are made in accordance with the ECN process detailed in HNF-IP-0842, VOL. IV, SEC. 4.29, Engineering Document Change Control Requirements.

\subsection{Configuration Management of the Project Interfaces}

Interfaces with existing plant SSCs, other projects, and the Program are described in HNF-SD-W314-PICD-001, Project Interface Control Document for W-314. Release and approval of this document is accomplished by obtaining the affected organizations' approval. Revisions are made in accordance with the ECN process detailed in HNF-IP0842, VOL. IV, SEC. 4.29, Engineering Document Change Control Requirements.

\subsection{Configuration Management of the Quality Requirements}

The Quality Assurance Program Plan for Project $W$-314 (QAPP), HNF-SD-W314QAPP-001, describes the requirements for implementing the River Protection Project Quality Assurance Program Description, RPP-MP-599. Revisions to the QAPP are made in accordance with the ECN process detailed in HNF-IP-0842, VOL. IV, SEC. 4.29, Engineering Document Change Control Requirements.

\subsection{Configuration Management of Supporting Documents}

As determined by the Project Management staff, miscellaneous reports are released as

Supporting Documents when retrievability and structured document control is desired. A list of Supporting Documents issued by W-314 is available through the Hanford 
Document Control System (HDCS). The documents are released in accordance with the EDT process identified in RPP-PRO-244. Revisions are made in accordance with the ECN process detailed in HNF-IP-0842, VOL. IV, SEC. 4.29.

\subsection{Management of "In-Process Information"}

In-Process information consists of direction and correspondence provided to the Design Agent for development of the Title II design. Contractual requirements are communicated through the $\mathrm{CHG}$ contracts office. Other direction, such as comments and resolutions from design reviews, will be communicated through $\mathrm{CHG}$ Project Management.

\subsection{Configuration Management of Control System Software}

The Software Configuration Management Plan (SCMP) is currently in development and will provide the instructions for configuration management control of the W-314 Project, Master Pump Shutdown System (MPSS) software. This plan applies to the MPSS software developed by the project, consisting of the computer human-machine interface (HMI) and programmable logic controller (PLC) software source and executable code, for production use by Tank Waste Operations. It will be approved and released in accordance with procedures RPP-PRO-244, Engineering Data Transmittal Requirements, HNF-IP-0842, Vol. IV, Sec. 2.18, Engineering Release and Approval Requirements, and subsequent revisions are controlled in accordance with HNF-IP-0842, VOL. IV, SEC. 4.29, Engineering Document Change Control Requirements.

\subsection{Configuration Management of Vendor Submittal Information}

Submittal requirements are identified in the construction and procurement specifications. The performing organization responsible for procurement maintains a master submittal log, identifying each submittal by a unique number traceable to each W-314 design

package. Submittals that are required for Vendor Information (VI) are managed, released, and revised in accordance with HNF-IP-0842, Vol. IV, Sec. 4.23, Vendor Information.

\subsection{Drawings}

Drawings are prepared and released in accordance with RPP-PRO-709, Preparation and Control Standards for Engineering Drawings.

\subsection{Configuration Management of "Turn-Over Documentation"}

Project W-314 develops an Acceptance for Beneficial Use (ABU) for each construction unit to be turned over, as applicable, per HNF-IP-0842, Vol. IV, Sec. 3.12, Acceptance of Structure, Systems, and Components. 


\subsection{Configuration Management of the W-314 RDD-100 Database}

Configuration management of the W-314 RDD-100 Database is provided by internal project management controlled by the System Administrator. Approved and released versions of the database will be stored by LMSI. This will be accomplished by releasing the software as a supporting document in accordance with HNF-IP-0842, Vol. IV, Sec. 4.2.6, Supporting Document Requirements. The supporting document will include text pages that provide the following information.

a. Project W-314 Application Software and Data. File control information consisting of:

- Directory structure

- File name

- File size

- Date file was created

- Time file was created.

b. Vendor Application Software. Program/file control information consisting of:

- Name of program/file

- Program/file identification number (if applicable)

- Program/file version identification number (if applicable)

- Directory structure

- List of files (name, size, date created, time created).

c. Platform. Platform control information consisting of (as applicable):

- Type of computer

- Type of CPU

- Operating system

- Memory manager and setup if unique

- Minimum memory

- Minimum hard drive size

- Required floppy drive

- Type of network and its setup if used

- Any other unique hardware and software needs. 


\subsection{REFERENCES}

HNF-IP-0842, Vol. III, Sec. 3.1

HNF-IP-0842, Vol. IV, Sec. 2.18

HNF-IP-0842, VOL. IV, SEC. 4.29

HNF-IP-0842, Vol. IV, Sec. 3.12

HNF-IP-0842, Vol. IV, Sec. 4.20

HNF-IP-0842, Vol. IV, Sec. 4.23

HNF-IP-0842, Vol. IV, Sec. 4.2.6

HNF-IP-0842, Vol. VIII, Sec. 1.1

RPP-PRO-233

RPP-PRO-244

RPP-PRO-709

RPP-PRO-1997

HNF-SD-W314-PMP-001
Configuration Management Implementation

Engineering Release and Approval Requirements

Engineering Document Change Control

Requirements

Acceptance of Structure, Systems, and Components

Engineering Specification Requirements

Vendor Information

Supporting Document Requirements

Baseline Change Control

Review and Approval of Documents

Engineering Data Transmittal Requirements

Preparation and Control Standards for Engineering Drawings

Construction Program Overview

Project Execution Plan for Project W-314 
DISTRIBUTION SHEET

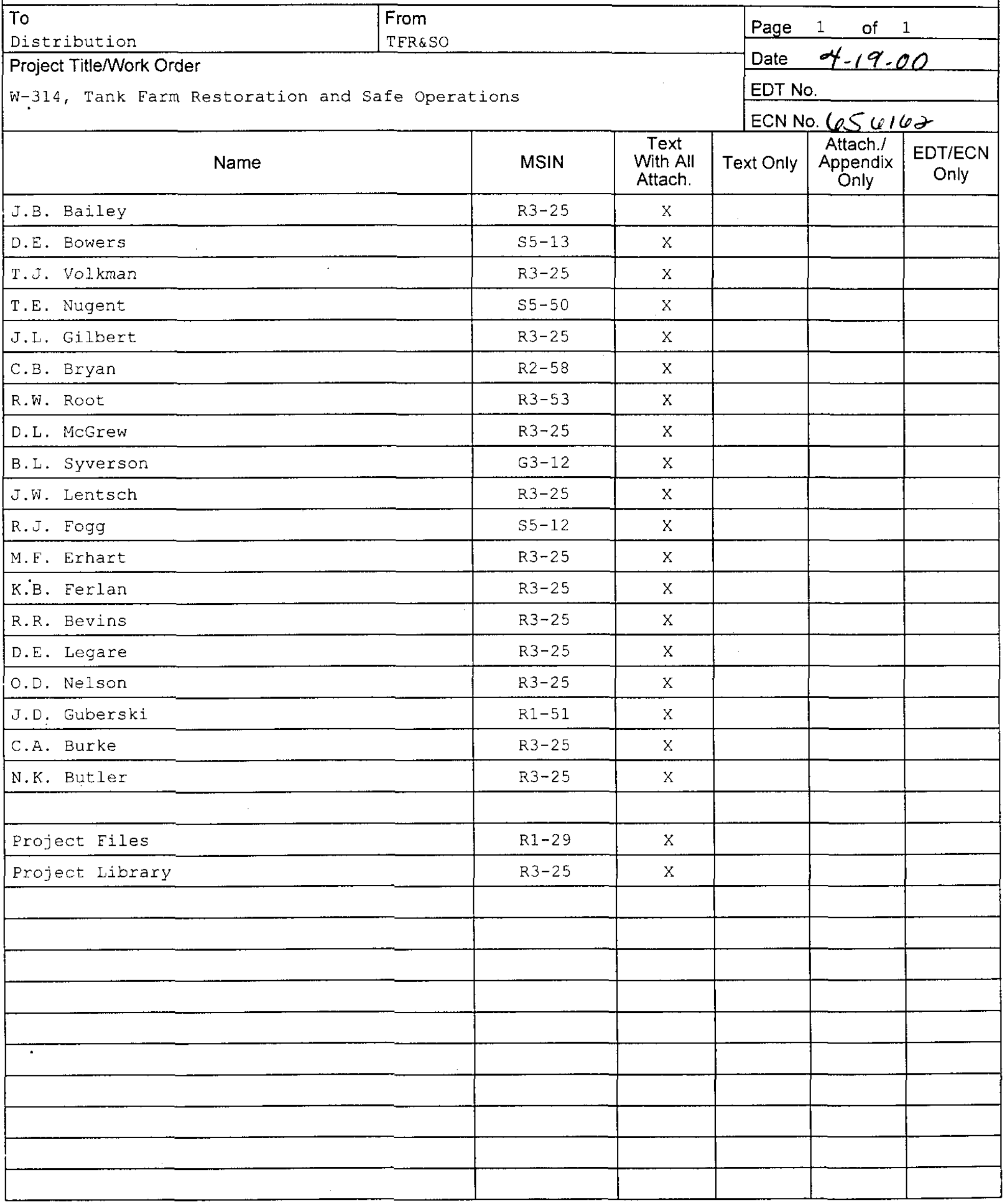

